\title{
Colombian Labor, Globalization and a Ray of Hope
}

\author{
James Rochlin, University of British Columbia - Okanagan
}

\begin{abstract}
While Colombian labor has been loathe to the country's recent consideration of a series of free trade agreements (FTAs), paradoxically debates surrounding the recently approved USColombia FTA have spawned greater security for unions and have attracted a global panoptic gaze with a capacity to protect and promote labor rights. But is too early to determine whether that capacity of liberation associated with global connectivity can translate into the establishment of human security for Colombian labor, the most besieged on the planet, from the wave of depletion it has endured since the 1990s. Between 2005 and 2010, 55 percent of all assassinations of trade unionists globally occurred in Colombia. ${ }^{1}$ We shall begin with an historical overview from which to consider the current plight of Colombian labor, and will then focus on pivotal events since the 1990s. Concentric spaces between classical realism, neo-Gramscian approaches, and Foucauldian thought are enlightening when analyzing both historical trends and future prospects. This piece will focus on unions in Colombia's petroleum sector, which historically have been a flagship for the country's labor movement, and which have attracted added significance in the context of the current global commodity boom.
\end{abstract}

\section{KEYWORDS}

Colombia, free trade, hope, labor

\section{Historical Overview}

Colombian labor unions evolved from sociedades de mutuo auxilio, or mutual support societies, that sprouted beginning in 1889 . The first major unions formed near the turn of the $20^{\text {th }}$ century, with the appearance of the Union de Industriales y Obreros in 1904 and the Union Colombia Obrera in 1913. Amidst the international repercussions of the Russian Revolution in 1917 , and the proliferation of socialist parties in many parts of the world, labor unions gained steam globally. With regard to Colombia, unions formed in reaction to growing United States (US) investment in the country during this period, especially in the agricultural and petroleum sectors. Colombia's first major wave of strikes occurred in 1918 at the port cities of Cartagena, Santa Marta and Barranquilla, and these were met by violent suppression on the part of military - initiating a 
pattern of barbarism that would be predominant over the next century. There were 26 unions in the country by 1919 (González 1975: 5, Pecaut 1973: 89).

During those early years two particularly noteworthy strikes occurred in the banana and petroleum sectors. There were two prominent cases of labor action in the oil patch during the years 1924 and 1927, and the issues were similar. Basic hygienic and health issues represented the most pressing concern. For example, 1,023 of 2,838 oil workers in the tropical city of Barrancabermeja fell gravely ill in 1923-24, prompting union demands for window screens in company housing to protect workers from insect-borne disease. Workers also stuck for workday regulations, such as a maximum eight hour shift and a day off on Sunday. The military forced the expulsion of nearly 1,200 workers from the city of Barrancabermeja during the 1924 oil strike (Urrutia 1969: 16). The banana strike of 1928 - featured in Gabriel Garcia Márquez’s classic One Hundred Years of Solitude involved a work stoppage by 25,000 workers that was met by a notorious massacre and wave of assassinations (Safford and Palacios 2002: 281). Overall, the petroleum and banana industries were bellwethers for labor issues in other sectors. It is important to emphasize that the 1920s initiated a pattern whereby the labor movement was generally viewed by government and business as a subversive socialist force that required violent repression. Since then, prominent labor leaders continue to be the targets of assassinations and horrific human rights abuses, as we shall see.

In the 1930s and 1940s, there was general progress in Colombia's union movement though labor was ideologically divided between whether to support fledgling socialist parties or the more traditional Liberal Party. Organized labor in Colombia was officially recognized in 1931, and an eight-hour workday was legally entrenched in 1934. The Confederación Sindical de Colombia (Colombian Confederation of Labor Unions) - an umbrella organization formed in 1936-1938 matured into the Confederación de Trabajadores de Colombia (Colombian Confederation of Workers) in 1943. Political organization and amalgamation among unions rendered them a more formidable force vis-à-vis government. Overall, the $1930 \mathrm{~s}$ and $1940 \mathrm{~s}$ witnessed the institutionalization of labor, which facilitated its role as the largest and most important political organization within Colombia's weak civil society.

A key turning point came during the National Front of 1958-1974, when the Liberals and Conservatives finally agreed to halt more than a century of violent feuds and mutual exclusion in their vain attempts to achieve hegemony. The Front was brokered by the US and Spain in an effort to drag Colombia out of non-modern warfare into the Modern and binary world of the Cold War, where Colombian politics would now be viewed through the Manichean lens of capitalism versus communism. During the National Front, the Liberal and Conservative Parties - which engaged in almost non-stop warfare shortly after Independence in 1821 - put aside their miniscule ideological distinctions and murderous political rivalry to jointly support a capitalist political economy and to declare their common warfare against the Left. Thus, the pattern of ultra-violence and exclusion persisted but transformed - instead of the neo-feudal clash between the two principal parties, the focus was now on escalating warfare between the Left and Right within the context of the newly emerging Cold War. Labor movements, especially those sympathetic to socialism, came under increasing suspicion, surveillance and harassment by the government during this period. Overall, for the government and the military, left-leaning unions were counted as among the enemy (Romero, 1999: 170-174). 
US security interests in Colombia were redefined alongside major shifts in the world order during the 1950s and 1960s. In its great contest with the Soviet Union, one that focused on developing countries beginning in the 1950s, a central problem identified by Washington was to prevent the growth of communism especially in its perceived 'backyard' of Latin America. Washington's interest in the country coincided with a 'national security doctrine' that relied on force to contain or eliminate Communism (Leal Buitrago 2002: 2-18). The clearest expression of Washington's intervention in Colombia during the 1960s was Plan Laso, which included a reorganization of the country's military to fight leftist insurgents. A specific manifestation of this in 1964 was Operation Marquetalia - led by the refashioned Colombian military - to curtail the emergence of peasant guerrilla movements, especially the Fuerzas Armadas Revolucionarias de Colombia (FARC). It is worth underscoring that Plan Laso represented the largest US military aid package in Latin America until the Reagan Administration's intervention in Central America during the 1980s. Colombia reclaimed the title of Latin America's largest recipient of US military assistance in the early 1990s (Rochlin 2007: 27).

This epoch also witnessed key developments vis-a-vis the genesis of paramilitary forces which emerged as a military force in the 1980s and as a political-military force in the 1990s and beyond. In 1965 the government of President Guillermo León Valaencia enacted legislation Decree 3398 - that created and promoted self-defense groups to fight against leftist insurgent movements. Their presence became more pronounced in the late 1970s and into the 1980s, when the paramilitaries began to serve a number of social functions. First, they acted as the illicit security wing for wealthy and sometimes even middle-class landowners against incursions by leftist guerrillas. Further, when the Colombian government started talking seriously about land reform in the 1970s as a method of coping with leftist forces, paramilitary units assembled and attacked leftist groups (Romero 2003: 133; Rochlin 2007: 21-42). Paramilitaries also protected those who came under the threat of kidnapping and extortion from guerrilla groups such as the FARC.

Beyond US military intervention in Colombia, its political influence was manifested through various means including the US labor movement - most particularly the AFL-CIO's American Institute for Free Labor Development (AIFLD). There was obvious concern on the part of Washington that Colombian unions would become influenced by Castroite force and the guerrilla left in the country, and AIFLD attempted to counter that possibility. The main thrust of AIFLD was to inculcate the US approach to labor relations through educational programs, social projects, meetings with Colombian labor groups, and so on (Buchanan, 1989: 46). One observer noted that it operated under the premise of 'what is good for US labor (and capitalism) is good for Latin American labor' (Spalding 1976: 46). Its intention, then, was to foster US-friendly unions that welcomed US investment and which supported global capitalism. As Aviva Chomsky observed, the ALF-CIO in the new millennium is trying to overcome the 'suspicion it has generated in Latin America' during that era, a point to which we shall return. ${ }^{2}$

The 1970s represented the peak of the Colombian labor movement in terms of its political power and the physical security of its members. It had achieved in 1966 the right to strike legally with a maximum limit of 43 days. By 1974, some 47 percent of finance workers were unionized as were 46 percent of industrial workers. However, a 1977 national strike proved to be an unmitigated disaster, and the tides generally turned against labor after that point. The situation of the petroleum union Unión Sindical Obrera (USO) was emblematic of the general strike results: no worker 
demands were met, 217 workers were dismissed from their jobs, and another 45 were detained by authorities for interrogation (Caicedo 1971: 231).

While the focus here is upon the plight of Colombian labor since the advent of Plan Colombia, the recent historical context is crucial and so an abbreviated sketch of the country's complex political cocktail is in order. By 1984, the 20-year-old FARC, Latin Americas largest remaining leftist guerrilla group, had created a 'legitimate' political wing through which it fielded candidates in local and national elections. It achieved modest success through its Union Patriótica party (UP), winning 14 Congressional seats in 1986, which suggested that a peaceful end to the country's nearly two centuries of warfare might be in the offing.

However, by the early 1990s, between 3,000 to 4,000 UP members were assassinated at the hands of paramilitary forces, a phenomenon which occurred with the complicity of government forces (FARC 1994). Sensing that there was no 'legitimate' political space in which to operate, the rebels chose an exaggerated Clausewitzean policy of power maximization though the use of escalating force with the objective of forming a parallel state and governing their own piece of territory. The Colombian military - still in its dinosaur stage and weighed down by poor organization, limited mobility, aging equipment, outdated training and astonishingly poor strategy - dithered while the FARC's power was clearly on the ascendant. The peak of the FARC's power came in 1998, when it had received from the strategically inept government Andres Pastrana a parcel of land about the size of Switzerland - the Zona de Distensión. This was supposed to be used as a ceasefire zone that would spawn conclusive negotiations. All this was highly encouraging for the FARC, which by now included almost 20,000 armed members and which was organized into 60 fronts across the country.

Two other developments during this period are particularly noteworthy. Another key belligerent force was growing rapidly - the right-wing paramilitary forces that were now acting at the behest of narcotraffickers. Paramilitary troops ballooned from about 1,800 in 1990 to 8,150 in the year 2000 (Ejército Nacional, 2000). The United States, for its part, largely ignored Colombia during most of the 1990s due to a repugnance toward Colombia's narco-related corruption and Washington's preoccupation with the signing and implementation of NAFTA. But it was the 1998 provision of the Zona to the FARC that prompted Washington to push the panic button during the same year that Hugo Chávez bolted to power in neighboring Venezuela.

The results of the US re-conception of the Colombian problematic were quick and profound. Washington's Plan Colombia (PC) entailed about $\$ 7$ billion in US funding over the first decade of the new millennium, with about 85 percent of that representing military aid. During its inception and first few years of implementation, PC displayed three remarkable traits: 1) its staunch reliance on the concept of privatization; 2) its reflection of a refracted Revolution in Military Affairs (RMA) refashioned for the global South rather than the previous targets of developed nations with nuclear arsenals or the Middle East; and 3) its principal objective of obliterating the FARC.

Colombian warfare is highly privatized. It is remarkable that a private military corporation, MPRI, was awarded a $\$ 4.3$ million contract to advise US authorities on how to restructure warfare in Colombia. PC has involved a wide array of private military and security corporations, and has also included military contract workers (neo-mercenaries) that officially are capped at 600 but whose number has never been monitored by organizations not linked to the Colombian and US governments. Private criminal funding - especially from narcotrafficking but also from extortion and other crime - has bankrolled the paramilitary forces which have had some 70 percent of their 
financing emanating from illicit narcotics. To a lesser extent and in a more nuanced manner, profits from illicit transnational capital have also financed the FARC while simultaneously deflating the credibility of their leftist ideological posturing - e.g., some FARC fronts admit a 10 percent tax on peasant coca growth though they deny any further engagement in the trade, a point hotly contested by numerous observers (Rochlin 2011).

PC was also formulated to reflect the RMA - with a special focus on eliminating complex insurgent forces in the global South. It entailed a reliance not only on the aforementioned feature of privatization, but also involved asymmetric warfare, panoptic ultra-surveillance, ultra-mobility, complexity, the discourse of terror, the blurring of crime and warfare, among other features. Thus, Colombia represented a theater for the general projection of US military power in developing countries. ${ }^{3}$ More particularly, the initial goal of PC was clearly to eliminate or severely diminish the power of the FARC in Colombia in a manner that could shed light on US military intervention in other countries where insurgents relied on crime and drug trafficking, such as in Afghanistan (New York Times 2011a).

Over the course of the decade, some key objectives of PC altered to adjust to rapid transformations in the world order. One of these shifts concerned the commodity boom - especially in the areas of petroleum and mining - that initially underpinned the ill-fated housing boom and then fed the voracious needs of China and other emerging powers. With regard to Colombia, especially after the ill-fated invasion of Iraq in 2003 and record oil prices by 2008, US interests turned from a uni-focus on weakening the FARC to the protection of petroleum production sites, pipelines and key mining activities. Indeed, Colombia was among the top ten suppliers of oil to the US during the latter part of that decade. A second major transformation occurred with reference to the drift to the Left among Latin American powers - ranging from the feverish anti-Americanism of Venezuela, Bolivia and Ecuador to the emergence of Brazil as an independently minded major power aligned with China, Russia, India and South Africa. Within this context, the US engagement in Colombia changed from its focus upon events within that country to the conversion of Colombia as a bastion of US military power from which to check the strategic ambitions of next-door-neighbor Venezuela and especially the rising power-house of Brazil.

\section{Labor and the Introduction of Neoliberalism}

Colombia's drug buoyed economy was able to ward off the drastic effects of the Latin American debt crisis during the 1980s, but it was the cascade in the 1990s into an ultra-violent power grab between guerrillas, paramilitaries and a feeble state that led to the implementation of International Monetary Fund (IMF) restructuring policies. Annual levels of foreign investment collapsed by 70 percent between 1993 and 1999 (New York Times 2000), as investors headed for the exits against the backdrop of hyper-violence in the country. While the economy grew at a decent rate of between 4 and 5 percent during the period 1994-1998, Colombia sank into a deep funk at the turn of the century worse than that experienced during the Great Depression. The economy fell 4.5 percent in 1999, when industrial production slid 17 percent. Unemployment rose to at least 20 percent. The country's foreign debt doubled between 1998 and 1999, while debt rating agencies 
such as Standard and Poor's downgraded its economic rating from stable to negative in April 2000 (El Tiempo 2011).

An IMF restructuring package was implemented in 2000, ushering in increased taxes, a wave of privatization, and sharp cuts in social welfare, while the repressive sector benefited from a windfall of geometric proportions - a point to which we shall return. Exchange rates roughly doubled between 1997 and 2002, and during the later year 40 percent of government revenues were siphoned to debt repayments. Inequity, already one of the highest in the world, was exacerbated as the gini coefficient rose from .55 in 1991 to .59 in 1999 - placing Colombia among the three most inequitable countries in Latin America along with Mexico and Brazil (World Bank 2000). Overall, the introduction of the neoliberal doctrine meant a growing wave of privatization that eliminated union jobs in favor of unprotected contract work. Union membership declined from .0538 percent of the active workforce in 1994 to .0428 in 2002 (Gobierno de Colombia 2002). Indicative of this trend, membership in the oil union USO fell from 13,500 members in 1994 to 2,350 members in 2004 (Interview, Ríos 2004). 
Table 1: Human Rights Violations Against Colombian Union Members During Three Presidential Administrations

\begin{tabular}{|c|c|c|c|c|}
\hline $\begin{array}{c}\text { Type of } \\
\text { Violation }\end{array}$ & $\begin{array}{c}\text { President } \\
\text { Pastrana: } \\
\text { 1998-2002 }\end{array}$ & $\begin{array}{l}\text { President } \\
\text { Uribe: } \\
\text { 2002-2006 }\end{array}$ & $\begin{array}{l}\text { President } \\
\text { Uribe: } \\
\text { 2006-2010 }\end{array}$ & Total \\
\hline Threats & 1,272 & 1,298 & 1,215 & 3,785 \\
\hline Homicides & 580 & 362 & 166 & 1,108 \\
\hline $\begin{array}{c}\text { Forced } \\
\text { Displacement }\end{array}$ & 264 & 146 & 388 & 798 \\
\hline $\begin{array}{l}\text { Arbitrary } \\
\text { Detention }\end{array}$ & 209 & 206 & 89 & 504 \\
\hline Harassment & 57 & 138 & 93 & 288 \\
\hline Physical Attack & 70 & 43 & 40 & 153 \\
\hline Kidnapping & 108 & 29 & 0 & 137 \\
\hline Disappearance & 46 & 22 & 11 & 79 \\
\hline $\begin{array}{c}\text { Breaking and } \\
\text { Entering - Home }\end{array}$ & 3 & 17 & 10 & 30 \\
\hline Torture & 4 & 8 & 12 & 24 \\
\hline $\begin{array}{c}\text { Murder of } \\
\text { Relatives }\end{array}$ & 1 & 0 & 0 & 1 \\
\hline Total & 2,614 & 2,269 & 2,024 & 6,907 \\
\hline
\end{tabular}

Source: Escuela Nacional Sindical, Cuaderno de Derechos Humanos, \#22, October 2010, Medellín, p. 30. 
Table 2: Number of Homocides Of Colombian Union Members: 1986-2010

$\begin{array}{lc}1986 & 36 \\ 1987 & 73 \\ 1988 & 138 \\ 1989 & 96 \\ 1990 & 58 \\ 1991 & 96 \\ 1992 & 141 \\ 1993 & 201 \\ 1994 & 104 \\ 1995 & 229 \\ 1996 & 277 \\ 1997 & 171 \\ 1998 & 99 \\ 1999 & 83 \\ 2000 & 138 \\ 2001 & 193 \\ 2002 & 191 \\ 2003 & 101 \\ 2004 & 95 \\ 2005 & 72 \\ 2006 & 78 \\ 2007 & 39 \\ 2008 & 51 \\ 2009 & 47 \\ 2010 & 51\end{array}$

Source: Escuela Nacional Sindical, Cuaderno de Derechos Humanos, \#22, 2010, Medellín: and Interview by author with Guillermo Correa, Director of Research, Escuela Nacional Sindical, 16 February 2011. 
Table 3: Number of Human Rights Abuses Against Colombian Union Members, 1 January 1986 to 30 August 2010

$\begin{array}{lc}\text { Threats } & 4,826 \\ \text { Homicides } & 2,842 \\ \text { Forced Displacement } & 1,696 \\ \text { Arbitrary Detention } & 632 \\ \text { Harassment } & 310 \\ \text { Physical Attack } & 274 \\ \text { Disappearance } & 217 \\ \text { Kidnapping } & 165 \\ \text { Torture } & 82 \\ \text { Home Break and Enter } & 49 \\ \text { Murder of Family Member } & 3\end{array}$

Source: Escuela Nacional Sindical, Cuaderno de Derechos Humanos, \#22, October 2010, p. 46.

Table 4: Foreign Direct Investment in Petroleum Sector as a Percentage of Total FDI in Colombia; Petroleum as a Percentage of Total Export Value; and Annual GDP Growth

$\begin{array}{cccc}\text { Year } & \text { Share } & \begin{array}{c}\text { Percentage of Total } \\ \text { Export Value }\end{array} & \text { GDP Growth } \\ 2001 & \text { FDI } & 43 \% & 1.7 \% \\ 2002 & 20 \% & 36 \% & 2.5 \% \\ 2003 & 20 \% & 39 \% & 3.9 \% \\ 2004 & 15 \% & 38 \% & 5.3 \% \\ 2005 & 15 \% & 40 \% & 4.7 \% \\ 2006 & 12 \% & 40 \% & 6.7 \% \\ 2007 & 30 \% & 37 \% & 6.9 \% \\ 2008 & 38 \% & 47 \% & 2.7 \% \\ 2009 & 32 \% & 51 \% & .8 \%\end{array}$

Source: Data regarding petroleum as a percentage of value of total Colombian exports, and date regarding GDP growth from World Bank, World Development Indicators and Global Development Finance Databases, viewed 26 April 2011.

Data regarding FDI from Banco de la República, as shown in Escuela Nacional Sindical, Panorama de la Inversión Extranjera en Colombia, 2010, p. 13. 
Table 5: Crude Petroleum Production in Colombia 2000-2010

$\begin{array}{lr}\text { Year } & \text { Metric Tons } \\ 2000 & 2861 \\ 2001 & 2512 \\ 2002 & 2430 \\ 2003 & 2278 \\ 2004 & 2276 \\ 2005 & 2238 \\ 2006 & 2319 \\ 2007 & 2293 \\ 2008 & 2511 \\ 2009 & 2880 \\ 2010 & 3372\end{array}$

Source: United Nations, Monthly Statistics Online, Colombia Crude Petroleum Production, 2000-2010, viewed 26 April 2011.

\section{The New Millennium: Plan Colombia, 9/11 and the New Political Landscape}

There were three important trends at the beginning of the new millennium that had a profound effect on trade unionists in Colombia, especially in the oil sector. These include the initiation of Plan Colombia in 2000, the effects of the 9/11 attacks a year later combined with the 2003 invasion of Iraq, and the demobilization/negotiation process involving the paramilitaries that began in 2003. The implementation of the multi-billion Plan Colombia, which rendered the country to be the third largest destination of US military assistance at various points in the decade, meant a triad of severe implications for labor. First, as we noted earlier, PC incorporated an ideology of neoliberal privatization that proved to be pervasive throughout the political economy. Not only did the Plan involved the privatization of warfare, but Colombia itself emerged as Washington's flagship for a refashioned neoliberal economy that featured the privatization of formerly state corporations against the backdrop of a steady nationalist drift among many Latin American countries. There is widespread agreement among Colombian labor and its supporters that 'the biggest threat to unions is privatization', since it generally meant the replacement of unionized employees with non-unionized contract workers (Interview, Schipull 2004). In fact, the aforementioned IMF restructuring policy was implemented the same year as the initiation of Plan Colombia. That agency, along with the World Bank and the Inter-American Development Bank, represented the institutional handmaidens for a widespread policy of privatization that contributed to the demise of union membership in the country (Interview, Gómez 2004). 
A second effect of the initiation of Plan Colombia was related to the ultra-surveillance associated with the RMA. This meant not only the implementation of intense satellite surveillance indeed, Colombia was the first Latin American country to be completely targeted by aerial surveillance to a resonance of nine meters from the ground in the attempt to defeat the FARC - it also meant a wide array of human intelligence. One component of this was a system of paid informants, whereby any citizen could phone a toll-free number and report 'suspicious' activity without any hard evidence (Rochlin 2007: 54). This prompted a situation whereby union members were harassed and accused, often without evidence, of being linked to leftist guerrilla groups. A leader of the oil union USO indicated that President Uribe had 'stigmatized' union members as collaborators with leftist insurgents, and that USO members had been under siege in the wake of false intelligence reports against them (Interview, Ríos 2004). This was related to a series of detentions of trade unionists falsely accused of links with the guerrilla left (Interview, Rosada Duque 2004). Based on series of cases throughout the decade, Jorge Noguera, the Director of the country's intelligence agency Departamento Administrativo de Seguridad (DAS) until 2005, was arrested in 2007 and subsequently convicted of conducting illegal intelligence activities against union members and providing the names and contact information of key union leaders to paramilitary forces for assassination.

A third and crucial effect of Plan Colombia upon the country's labor movement emanated from the accelerated proliferation of paramilitary forces, which are estimated to have grown from over 8,000 in the year 2000 to some 20,000 by 2006 (Rochlin 2007: 87). Indeed, the paras were an important feature of the RMA. Regarding the privatization of warfare, they have demonstrated considerable utility as privately funded non-state combatants against the guerrilla left. With regard to their role in asymmetric warfare, there were cast as 'right-wing' guerrillas fighting on a level playing field with their leftist counterparts. Table 2 indicates a surge of assassinations of trade unionists between 2000 and 2003, the first four years of PC, after the lull of 1998-1999 that was marked by peace negotiations between the government and the FARC. Union leaders regard paramilitary forces as the over-riding perpetrator of assassinations, threats and other abuses toward labor (Interview, Torrado 2004, Gómez 2004, Ríos 2004, Schipull 2004).

While Plan Colombia retained the outlines of its basic shape, its direction was altered significantly by global implications emanating from the 11 September 2001 attacks and the subsequent invasion of Iraq in 2003. Further, Plan Colombia was tweaked in 2002-2003 by the effects of the failed coup against Venezuela's Hugo Chávez, and the steady leftward drift of many Latin American states during the first decade of the new millennium. While these seminal events occurred during the beginning of the decade, their clearest effects did not become apparent until 2006 and beyond. Let us explore these further.

While the expense and magnitude of Plan Colombia placed Latin America back on the strategic map for the US, its global significance for Washington was challenged by the context of the 9/11 attacks, the preoccupation with Bin Laden and the 2003 invasion of Iraq. Now PC had to compete with top shelf global strategic issues such as Islamic terror and Middle Eastern quagmires for Washington's attention and money. That task proved easier due to the rising price of oil that resulted both from the invasion of Iraq and from the increasing appetite for petroleum from emerging powers such as China. That is, Colombian oil seemed increasingly precious against such a backdrop. Further, a series of desperate and failed destabilization plans during 2002-2003 in 
Venezuela, Latin America's biggest oil economy with the world's largest proven reserves of oil, also led petroleum companies to consider more seriously prospects in investment-friendly Colombia.

As we see from Table 4, foreign direct investment (FDI) in Colombia's oil sector as a percentage of total FDI ballooned from 12 percent in 2005 to 30 percent in 2006 and 38 percent in 2007. Thus, it took a couple of years for the effects of the aforementioned events to translate into actual dollar investment in Colombia's oil patch, though this brief gap is what one would expect given the time it takes for major oil companies to shift gears into newer and more uncertain territory. No doubt this trend was underpinned by the greater security provided by Plan Colombia to TNCs in the extractive sector, a topic to which we shall return. Oil revenues jumped about 80 percent between 2004 and 2006. Petroleum increased to a range of between 47 to 51 percent of the country's total export value in 2008-2009 from a range that was generally below 40 percent earlier in the decade.

All this meant a new context for trade unionists in the oil sector. USO, historically a lightening rod for the general climate of labor politics in the country, initiated a strike in 2003 to oppose what it claimed was the imminent privatization of Ecopetrol, Colombia's state-owned oil company. USO argued that not only would such a prospect be detrimental for labor by accelerating the push toward non-unionized contract workers, it would also mean that the profits from the industry would be siphoned off to foreign owned companies (Interview, Ríos 2004). President Uribe responded to the strike by declaring it illegal since, he argued, petroleum production was an essential service. He proceeded to fire 263 striking employees of Ecopetrol, including key labor leaders associated with USO. The International Labor Organization responded to the crisis by insisting the strike was indeed legal. A year after the mass firings, all but 34 were hired back and USO struggled on their behalf. The President of USO argued that the strike ultimately was successful, since it drew international support from the ILO and globally publicized the nature of union struggle in the country. Further, USO leaders indicated that the strike demonstrated this particular union's role as the first major labor organization to confront Uribe, and that this was consistent with its historical place within Colombian labor. Rather than privatization, USO favored nationalization and 'antiimperialism' (Interview, Vaca Cespedes 2005; Alvis 2005). USO's rank and file had fallen from 13,500 members in 1994 to less than 2,300 by 2006 (Interview, Ríos 2006).

A decisive turning point for Colombian unions occurred with the commencement of government negotiations with paramilitaries that began in December 2002 (Romero 2003, Hristov 2009). The officially stated goal was to demobilize the illicit paramilitary forces and to incorporate them into society, a process that began in the middle of 2003. By the middle of 2006, 31,000 paras had demobilized, surpassing government estimates of paramilitary forces in the range of 20,000. The process was under-girded by the 2005 Law of Justice and Peace, which critics suggest provided impunity to the largest perpetrators of human rights abuses in the country as a result of the paramilitaries' strategic alignment with, and influence over, government forces. The New York Times, not known for radical stances, deemed the legislation to be the 'Impunity for Mass Murderers, Terrorists and Major Cocaine Traffickers Law' (New York Times 2005). It limited maximum criminal sentences to five to eight years, 18 months of which could be served at large zone designated for paramilitary residence and control (Rochlin 2007: 87-89). The move suited US and Colombian interests by officially removing a magnet of global criticism emanating from the crime and human rights abuses perpetrated by the paras for years. It also initiated what turned out to be a 
shell game whereby paramilitary members laid down their arms and tended to receive very lenient punishments for their crimes. Thousands appear to have regrouped into other paramilitary organizations as the decade proceeded.

The paramilitary demobilization process, and especially the dubiously lenient judicial proceedings associated with it, meant that the paras needed to be on their best public behavior. This spelled huge implications for Colombian labor. As Table 2 demonstrates, assassinations of union leaders during the first decade of the $21^{\text {st }}$ century dropped from a peak of 193 in 2001 to 101 in 2003 - the first year of the demobilization process - to a low of 39 homicides by 2007 . The demobilization process was an important contributing factor to this steep decline in assassinations of union members. Importantly, however, union leaders and their compatriots argue persuasively that the politics of fear/violence/exclusion persisted, though it transformed in its manifestations. Union leaders argue that paras switched from a policy of killing multiple union members in a single incident to a tactic of 'selective assassinations' of trade unionists, whereby the victim was selected for the magnitude of political impact that his/her murder would generate. Further, death threats against union leaders continued at virtually the same level between 1998 and 2010, at Table 2 indicates, suggesting again that paramilitaries perpetuated their strategic goal of weakening labor through policies of terror, but achieved this through tactics that produced fewer carcasses (Interview, Támara Rivera 2004, Ramírez 2004, Vásquez 2007, Silverman, 2008).

\section{Commodity Boom and Free Trade Prospects}

While labor feared the increased level of privatization that the free trade agreement with the United States might bring, paradoxically the protracted debates associated with the agreement that occurred at a global level helped draw the attention of global civil society to the plight of Colombian unions. The initiation of the deliberation process for United States-Colombia Trade Promotion Agreement occurred in November 2006, ushering in the second Uribe Government that lasted until 2010. The conception of the FTA was the result of important trends affecting Colombia's political economy. Let us consider these.

First, an important contextual factor was that Colombia was perhaps the most neoliberal of any major Latin American country. Even Mexico, Washington's other very close ally in the region, finds its conservative approach to be tempered with remnants of the country's statist or 'revolutionary nationalist' past, which lingers through policies such as strong national control of oil through the state-owned PEMEX. So while so much of South America moved left since 1998 including Venezuela, Bolivia, Argentina, Uruguay, and Ecuador - Colombia was perhaps the most inviting suitor for American and other international business. This was augmented by a second factor, the rise of the commodity boom that we observed earlier to be in full swing by 2006 especially in the mining and energy sectors. Given nationalist energy policies of neighboring Venezuela and Ecuador, Colombia's commodity bounty proved increasingly attractive for transnational investors.

Thirdly, the 'government take' on foreign oil investment in Colombia - the sum of all taxes, royalties and so on - dropped jaws with its sliding rate of between 5-25 percent (Interview, Unda 
2008). This compared to 86 percent in neighboring Venezuela, and similar rates in other OPEC member countries. However, Colombia's low government take is not the only cost foreign oil companies must pay for the privilege of operating in the country. Guerrilla warfare and criminal activity exact a price from TNCs through significant expenditures associated with private military/security services. In addition, there may be payoffs to guerrillas to ward off attacks and kidnappings that range near 10 percent of the company's local profits, as well as payments to paramilitary forces for protection. Further, a startling five percent of the country's gas is reported as 'stolen'. But petroleum companies allegedly turn a blind eye to the provision of such oil to paramilitary forces, who distribute the gas locally to garner social support for the paras and therefore generate security for petroleum corporations (Rochlin 2007: 76). No doubt TNCs in Colombia have accountants who calculate exact costs for these sorts of activities, though such figures are not publicly available. What is clear, as we saw earlier with Table 4's demonstration of the pace of foreign direct investment in Colombia's energy sector, is that the overall cost of investment in Colombia is relatively attractive.

Security for TNCs in the extractive sector has been improving in Colombia. One measure of this is belligerent attacks on oil pipelines. Remarkably, the Caño-Limon pipeline was bombed over 1,000 times between 1999 and 2003. But pipeline bombings for the entire country dropped to 20 in 2005, 53 in 2007, 32 in 2008 and 10 in 2009 (Interview, Garcia Chadid 2009; Rochlin 2007: 7173). There were at least three bombings of Caño-Limon in the first four months of 2011 (Colombia Reports 2011). So, while attacks in the extractive sector have diminished, they have not ceased. The same pattern is generally true of other types of belligerent activity and crime. Reduced rates of crime and guerrilla attacks are no doubt a partial result of the nearly $\$ 7$ billion in mostly military aid provided by Plan Colombia, which has spawned major improvements for Colombia's security apparati in terms of both training and materiel. Further, US forces and better-trained Colombian security forces have been dispatched to regions where petroleum production and transport are concentrated (Rochlin 2007: 71-74). It is worth noting that the country's armed forces more than doubled between the year 2000 and 2009 to 260,000 and have increasingly worked in concert with an expanded police force. Kidnappings decreased from about 3,000 in 2002 to 89 in the first four months of 2010, while the homicide rate fell from 65.8 per 100,000 inhabitants in 2002 to 33 in 2008 (Fundación Libre 2009).

\section{Non-Traditional Energy Resources: Colombian Labor and Biofuel}

Colombia's energy sector includes not only traditional resources such as petroleum, but also features an increasing emphasis on biofuels. The African Palm is the crop of choice, since its has the lowest production costs of major oils, it uses less land than other oil crops while generating a higher yield, and provides nearly eight times the energy yielded by other plants (Corely 2009, Escobar 2009: 1279). While most palm oil plantations are located in Malaysia, Indonesia and Thailand, the largest producer in the Americas is Colombia, which held about two percent of total world production in 2008 (Interview, Castro Forero 2008). In 2011, there are approximately 940,000 acres of palm plantations devoted to biofuel in the country. Workers on palm plantations are 
generally not unionized, which in some important ways works at cross purposes for the official goals of this expanding project - a point to which we shall return.

The production of biofuel derived from palm oil serves a number of objectives for both the US and Colombian governments. Indeed, palm oil plantations dedicated to fuel production usually entail what one observer has deemed to be an 'industrial complex' between TNCs, state capital and government agencies (Pye 2010: 854). The purpose of this arrangement is to achieve clear state objectives for greener energy sources. A public-private partnership is usually necessary due to the investment required to begin such an enterprise, especially because of the time span of between two to seven years for palms to reach maturity. This interim necessitates significant capital for workers, technology, fertilizers and so on.

From the Colombian perspective, biofuel such as palm oil serves a number of objectives that led the government to declare in 2004 that diesel engines must use 5 percent biodiesel (diesel mixed with 5 percent palm oil). That figure rose to 10 percent under a 2007 law, with promises of elevating it further to 20 percent within a decade. First, palm oil's contribution to biodiesel means a cleaner and greener environment for Colombia's notoriously polluted cities by reducing fossil fuel emissions. Second, the country's growing reliance on green sources of energy allows for the export of an increased proportion of Colombia's fossil fuels. An expanding palm crop has also permitted increasing exports of biofuel, especially to the United States. Third, biofuel derived from palm oil could help accelerate rural development in Colombia's hinterland, thereby providing jobs to peasants who might otherwise feel hopeless enough to considering support for leftist guerrilla groups. Fourth, and related to this, the Colombian government has publicly stated its hope that biofuel production can lead peasants away from coca growth and also help provide livelihood for peasants displaced by the country's internal war. For example, a 15,000 hectare palm plantation has been established in the department of Norte de Santander as an alternative development project to replace the tendency for coca growth (Interview, Castro Forero 2008; Martinez 2010: 1314-1319; New York Times 2011b; Boons and Mendoza 2010: 1692). This goal of reducing coca growth is also related to the task of eroding peasant support for guerrillas, since some FARC fronts protect peasants engaged in coca growth (Rochlin 2007: 43-62).

Beyond Colombia's objectives in the realm of biofuel, the United States is also interested in the country's palm oil energy projects. The US has invested considerable technical assistance for palm oil plantations to produce biodiesel (Interview, Vera Díaz 2008). Perhaps the clearest indication of American interests in Colombia's biofuel is a provision under the proposed ColombiaUnited States Free Trade Agreement that import duties on biofuels entering the US will be eliminated (Pinzon 2007).

Despite what seems like highly positive aspects of the palm oil plantations, interviews conducted with local workers indicate that poor labor conditions threaten to offset government objectives, especially with regard to drug eradication and perhaps with regard to 'green' aspects of the crop. In a group meeting of 12 unionized palm oil workers in San Alberto, Cesar - a small farming community about three hours away from the major city of Bucarramanga - workers indicated that only 210 of more than 3,000 workers at the local plant are unionized. Unionized workers at the plantation earn about USD $\$ 50$ per week. While their salary is similar to nonunionized workers, the small percentage of unionized workers receive benefits such as yearly paid vacations, health coverage and some degree of job protection. Worse conditions, they said, were 
faced by workers on cooperatives, which they compared to 'feudalism' and 'slavery'. This is due to the farmers' reliance on local palm oil companies for subsistence, fertilizers and so on until crops reach maturity, and also because of their dependence on the local refinery for their produce. Workers on cooperatives are not permitted to strike. Further, local crops in this San Alberto region were hit in the winter of 2011 with a fungus infestation, meaning many crops needed to be destroyed and replanted. The plantation owners used this as an opportunity to dismiss long-standing and better-paid older workers when the crops were destroyed and to hire lesser paid younger workers to replant. ${ }^{4}$

The workers in San Antonio reside in a region dominated for years by paramilitary forces, and while some had received threats from the paras in the 1990s when the region was contested, no such intimidation against labor has occurred within the last few years. A different story was told by 15 workers from Meta, a jungle region where the FARC is strong and where their power is contested by US and Colombian military forces in confunction with paramilitary troops. It is a major coca growing region of the country, with the FARC admittedly receiving a 10 percent tax on crops its 'protects'. Palm workers reported regular threats from the paras, against a local backdrop whereby labor is socially stigmatized as FARC supporters if not members of the guerrilla group. These workers indicated that they did not want to be burdened with coca cultivation - given its links to belligerent forces, the prospects of anti-coca fumigation, and so on. But all the workers interviewed indicated that there is still far more money in growing coca than palm trees in Meta, and that the low wages of palm workers and the lack of benefits received by non-unionized employees makes coca farming an option worth considering and popular among many. ${ }^{5}$ Thus, if coca eradication and viable crop substitution programs are the objective of the Colombian and US governments in the region, this could be more readily achieved by better wages and/or benefits associated with a unionized work force. USO, the petroleum union, has indicated that workers in the palm oil industry would be better protected if they were allowed to join USO rather than having the labor union split between USO and Sintraimagra (Interview, Osman Mantilla 2007).

Finally, greater input from workers on palm plantations could assist in helping palm oil plantations to be greener. As community members and employees, they are on the front lines of any environmental threats associated with palm growth. Workers in both locations indicated that mature forests are cut down for palm plantations, reducing biodiversity and shrinking carbon sinks because natural forest is denser than plantations. Further, workers indicated that heavy amounts of fertilizers are used, contaminating local rivers such as the Magdalena and inflicting health problems on workers such as skin rashes. They suggested that their day-to-day insights could help achieve a more environmentally sustainable operation (Interview, Sintraimagra workers cited in footnote 5; and Cardon Alzate 2009; Escobar 2009; Yanez 2009; Boons and Mendoza 2010).

\section{A Glimmer of Hope Post-2006: the Global Gaze and Colombian Labor}

As Table 1 Demonstrates, while Colombian labor remained the target of horrific human rights abuses that remained the worst in the world, there was significant improvement in many ways during the final Uribe administration of 2006-2010. Assassinations of union members were lower 
than the two previous presidential administrations, and as Table 2 shows, these declined to the level of the 1980s when statistics were first compiled. Kidnappings of labor leaders declined from 108 during 1998-2002 to 0 in 2006-2010. While progress appeared on some fronts, these were weighed down by tactics such as selective assassination and persistently astronomical levels of death threats against Colombian labor. This perpetuated the political instruments of fear and exclusion through fewer cases of abuse. Overall, while any abuse of union members is totally unacceptable, fewer assassinations and other abuses against union members has to be counted as a good thing.

The utility of the global gaze for southern subaltern groups was perhaps first demonstrated by the Zapatista movement in Mexico, shortly after they called for a revolutionary surge during Nafta's birthday on 1 January 1994. The charismatic and intellectually accomplished Subcomandante Marcos, who is multilingual and possesses a $\mathrm{PhD}$, was an important contributing factor to the Zapatistas' uniquely successful use of the internet. Their connections with thousands of global supporters throughout North America, Europe and elsewhere sharply limited the array of action against the Zapatistas that was feasibly available to the Mexican military, which in the 1970s had 'disappeared' hundreds of guerrillas mostly in the state of Guerrero (Rochlin 2003 and 2007). But it would be harder for the Mexican military to assassinate rebels with a cool website, filled with engaging images and literature aimed at indigeneity and the peaceful pursuit of political inclusion for the globally excluded. This situation stood in stark contrast to the top-down deployment of surveillance by the prison guards in Bentham's original conception of the panopticon, which is analogous to governmental use of surveillance as a repressive instrument (Bentham 1995).

The Zapatistas made it look easy. But the competition is fierce for attracting the global eye, the dispersed millions gazing at their computer screen. The Zaptistas concocted an impressive and highly unique package - their leader's pop star looks, his rhetorical talent, the group's highly thoughtful and ground breaking political agenda, their promotion of indigenous causes during the anniversary of five hundred years post-Conquest, and the fact that they were pursuing their goal of social justice peacefully. The Colombian case is more prickly. The site of barbaric warfare between an assortment of insurgent groups and the state, the epicenter of narcotrafficking, and a less familiar space compared to the tourist Mecca of Mexico, rendered Colombia to be something short of eye candy on the Internet. It took more than a decade for Colombian civil society to attract global attention to their plight. Much of this has to do with the Free Trade Agreement. That is, once the United States engaged in negotiations with Colombia, Americans wanted to know more about the country. This stood atop a relatively small but growing wave of global interest since the inception of Plan Colombia, when global NGOs and transnational social movements demonstrated concern regarding human rights abuses apparent in the country's warfare, especially on the part of right-wing paramilitary forces.

Ironically, protracted debate regarding an FTA agreement - the embodiment of US-flavored neoliberalism and privatization that so threatened and decimated Colombian labor since the early 1990s - by 2006 delivered to Colombian unions a magnet for the global gaze that had alluded them for so long. While labor movements generally disdained both US military intervention through Plan Colombia and growing American political influence over the country since in 2000, unimagined benefits appeared later in the decade. As I reviewed dozens of interviews I had conducted with trade unionists in Colombia since the beginning of the decade, it was nothing short of remarkable that after 2006 a ray of hope through global attention seemed to revitalize the spirit of Colombian labor, 
though its ranks continued to deplete. Now the tables had turned, and rather than being the sole victim of the repressive instrument of surveillance, unions were able to utilize surveillance as a liberating tool. A leader of Central Unitaria de Trabajadores de Colombia (CUT), one of the few major umbrella labor groups in the country, indicated in 2006 that 'international attention is key to the security of CUT and other unions', and suggested that such attention was responsible for goading the Colombian government into providing private security for the most embattled labor leaders in the country (Interview, Mora Fodoy 2006). By 2010, the director for research at the Escuela Nacional Sindical indicated that the FTA debates provided Colombian unions with attention they badly needed and never had (Interview, Correa 2011).

Now American political and labor representatives seemed rather suddenly to devote a keen interest to the plight of Colombian labor, and began applying pressure on the US government to insist on better treatment for Colombian trade unionists if a FTA is to be implemented. The AFL$\mathrm{CIO}$, for example, strongly opposed an FTA with Colombia based on human rights abuses of Colombian workers (ALF-CIO 2011). Such measures included addressing the horrific impunity for crimes directed at labor leaders. Indeed, key experts agree that impunity is perhaps the biggest problem facing union members, since perpetrators of such abuses would not likely persist to the extent they have if they faced judicial punishment for their crimes (Interview, Malagón 2010). The impunity rate was 58.7 percent for the 2,709 assassinations that occurred between 1986 and May 2009 (Escuela Nacional Sindical 2009). In the spring 2011, President Santos has agreed to take measures to combat impunity, and it will be important to gauge his commitment and success as the process unfolds. What is important to emphasize is that such improvements would not have occurred without global scrutiny that has resulted from the FTA debates and the global gaze.

Beyond the protracted discussion of the FTA, considerable global attention has come from international organizations such at the International Labor Organization, which had established a permanent representative to Colombia in 2006 after providing important moral support to the USO strike of 2003. While representatives of labor unions praised the ILO's presence as another manifestation of benevolent global eyes, some disappointment was expressed that the ILO has no binding power in Colombia - in other words, the government can ignore ILO findings (Interview, Ríos 2006; Vásquez 2007; Rodríguez Ortega 2010). Nevertheless, the ILO provides another spotlight on the treatment of Colombian trade unionists that can help save their lives and promote better labor standards. Further, the ILO is a catalyst for sparking the interest and support of other transnational actors interested in labor, human rights, trade regimes and development.

Finally, an important qualification is in order regarding prospects for Colombian labor vis-àvis potential global supporters. While connectivity has drawn attention to Colombian trade unions from other unions in the North, political solidarity may be limited if workers in each country view each other as a competitive threat. This may prove increasingly relevant if a trend toward nationalism emerges in the world order against the backdrop of global economic crisis. 


\section{Conceptualizing the Path Toward Human Security for Colombian Labor}

\section{THE PAST}

Despite definitive distinctions between them, and the perils of eclecticism, it may be helpful to recognize the important concentric spaces between realism, marxism and postmodernism. That space can be highly valuable when analyzing the historical context of the current juncture in Colombia, and for pointing to the road forward for the achievement of human security for Colombian labor. That is, ideological purism breeds polarization, which, as we've seen, is a big part of the problem in Colombia. Perhaps it's time to tear down some of those ideological walls in pursuit of conflict resolution and peace.

Strains of classical realism go a long way in explaining the historical context through which Colombian unions have navigated. The country's legacy of almost non-stop warfare, violence and fragmentation are a product of the intensely competing self-interest that for realists defines political pursuits. We observed that, in many ways, Colombian history is characterized by the power maximization, the lust for power and the greed described by classical realists such as Thucydides and Machiavelli. ${ }^{6}$ What many scholars appreciate about realism is that it takes into account the capacity of the very worst elements of human behavior, rather than wishing them away. At the same time, however, the beauty of classical realism is that it is a nuanced and multi-faceted approach, rather than the cartoonist manifestations of it filtered through the prism of American Cold War realism. Thucydides, for example, emphasized the power of capital in politics, appreciated the importance of epistemological rupture, and argued that war could only be avoided when the most powerful among belligerents behaved magnanimously and offered meaningful concessions to promote valued peace. ${ }^{7}$ In the same vein, Machiavelli, especially in the Discourses but also in The Prince, emphasized the ultimate political power of consent rather than coercion, and saw the two as forming a duality. ${ }^{8} \mathrm{He}$ viewed the intense struggle between the 'haves' and 'have nots' as the primary catalyst of progressive politics. Given notions such as the power of consent, the value of peace, the political dangers of pronounced inequity, and potentially positive outcomes of political struggle, classical realism sheds light on the Colombian case.

Leftist political economy, and particularly the neo-Gramcian or Critical Realist approach, is crucial for understanding the Colombian imbroglio and labor's place within it. Instead of being viewed in isolation from realism, this approach can be complementary to it. A vivid testimony of this, in The Prison Notebooks, is that Gramsci appreciated Machiavelli's emphasis on practicality and upon realistic means toward achieving clearly defined political objectives (Gramsci 1971: 125-205). He appreciated realism to an extent that others on the Left seldom have. Gramsci and his compatriots filled in some of the crucial blank spaces in classical realist thought, and developed many important but unbaked notions advanced by such thinkers. Most importantly, the historical materialist approach observes the important influence that production and class wield upon politics and ideology, and vice versa. It considers key aspects of political economy that are key for analyzing security. Relentless warfare and other political violence in Colombia have occurred against the backdrop of a dependent, underdeveloped and largely staple economy distinguished by intense inequity. Workers struggled in neo-feudal arrangements, and the relative few that worked in industrialized settings were exploited to the extreme. Exaggerated political fragmentation and 
decentralization, combined with formidable geographic barriers that isolated populations, meant that class consciousness in Colombia was slow to develop. The appearance of unions in Colombia in the 1920s and 1930s was perhaps the first step toward class consciousness and class struggle in the country, and this was augmented in the 1960s by the ripple effects of the 1959 Cuban Revolution. It is also important to emphasize the pronounced historical weakness of the Colombian state meant that individuals and groups were left to fend for themselves in the economic sphere. This contributed to Colombia's notorious entrepreneurial dynamism, the staunch entrenchment of a laissez faire political economy, and the general lack of a conception of contraband since the state was uninvolved in so much of the economy. Gramsci's key concept of hegemony is especially relevant vis-à-vis the Colombian state. The country represents a classic case study for what happens when hegemony is absent, when social consent has not been established and so coercion rules the day. Thus, Colombian labor struggles within Latin America's most violent, right-wing and criminalized economy.

Foucault's primary contribution to political analysis concerns his focus on the relation between power and epistemology. Of the three approaches considered here, perhaps this is the most fundamental. That is, the way in which people know what is true, and the limits of knowledge systems, are the basic parameters for conceptualizing politics (or anything else). Foucauldian thought shares conceptual space with both realism - by defining power as getting someone to do something he/she ordinarily would not, by its tweak of Clausewitz's notion to suggest that politics is the continuation of war by other means (Foucault 1997: 14-16), etc - and with Marxism - since, for example, the historical epistemological ruptures Foucault emphasizes are identical to the ruptures of historical materialism observed of Marx.'

While is of utmost importance not to impose the Northern knowledge systems upon Colombia or place Western epistemology on a pedestal, there are key features of Western Modernism - warts and all - that have fostered relatively stronger and more secure unions in the developed West, and key areas of the South, than in Colombia. Non-modern and feudal epistemes were predominant in Colombia until the early $20^{\text {th }}$ century - a relic from Spanish colonialism that was slow to dissolve for reasons discussed earlier. A Modern nation state that monopolized the use of force, institutionalized conflict resolution mechanisms, a state presence across the country, political legitimacy, and notions of balance and human rights have proven to be illusive for Colombia. This is true not only with respect to comparing Colombia to the North, but to Brazil, Argentina, Venezuela, Mexico, Chile and other states that have achieved some key components of the Modernist ideal.

Overall, the three major approaches to global politics are enlightening in their own way. But the synergy between them - including both their common elements and their distinct contributions - can lead to a richer understanding of the Colombian political context in which labor unions continue to struggle. A willingness to appreciate the contributions of a variety of conceptual approaches is more likely to promote conflict resolution than the isolating effects of purist ideological doctrines. Given the profundity of divisiveness plaguing the Colombian state and society, constructive insights from wide range of ideological and epistemological angles are most welcome. 


\section{THE GOAL}

The concept of human security is especially relevant to the plight of Colombian labor, since its purpose is simultaneously to propel development as well as peaceful conflict resolution (United Nations 2003). Conceptually and methodologically, it entails a process of knowledge creation and mobilization that insists on including the excluded. This means a 'bottoms up' conception to security and development, often with support from international networks. Due to human security's focus on human welfare in relation to security, it is underpinned by the Foucauldian view that the human body is the ultimate site of power. Foucault's 'biopolitics' entails the concept of a living social body that underpins various regimes of economy and security (Foucault 2000: 73-80 and 2003). The concept of human security builds on the approach of post-development that emerged as the Cold War waned, which is a product of scholars from the global South including the noted Colombian intellectual Arturo Escobar (Escobar 2003 and 1995, Esteva 1987 and 1991, Khondker 1999). The central aim of human security is to empower local actors, such as Colombian labor, to be agents of both development and security.

\section{Future Prospects and Problematics}

Just as the three major conceptual approaches can be useful in probing the historical context faced by Colombian labor, they can also point to feasible paths for the achievement of human security for unions. The postmodern perspective, for example, points to rays of hope. The global panopticon can be employed by subaltern forces, as Colombian labor is beginning to discover. Global network organization and transnational social movements can provide solidarity against the local forces of violent repression - here the constrictive duality of Inside/Outside noted by Walker may be broken (Walker 1993). Ultra-movement and the time-space compression underpin these developments. Just as goods, people and services move across borders at lightening speed, so, too, does information that can shine the global floodlights on the political carnage in Colombia that until recently was largely obscured.

Foucauldian thought helps raise some pressing questions. While Colombian labor has the attention of NGOs and politicians in the US and elsewhere, will that dissipate if the FTA is actually signed or the project is abandoned? How can Colombian labor sustain the global gaze against the backdrop of so much competition for it? Given the realist appreciation that Colombian labor recently has suffered fewer assassinations only because of the global gaze, this is key.

We observed that critical realism blends the one-size-fits-all power politics of classical realism (self interest as the principal guide to political action, the quest for power maximization in an anarchical system, the use of force, pessimistic assessments of human behavior, strategic alliances, etc) with forward looking post-Marxist approaches that emphasize Gramscian thought (the centrality of production in politics, an appreciation of class politics, and a reliance on a progressive view of historical materialism that does not privilege the economic base of class relations and mode of production at the expense of minimizing ideological and cultural factors). Class analysis can be employed to achieve positive results for Colombian labor. Some key problematics emerge in this regard. Realist perspectives emphasize the importance of self interest as a principal motivator of political action. Now that Colombian labor has received global attention, how can policies be shaped 
toward the establishment of enlightened self interest, that is, the movement toward achieving converging self interests and in emphasizing concentric areas of interest between business, the state and labor? How can sometimes contradictory interests be bridged between workers in Colombia and those from developed countries?

For the first time in its historical struggle, human security may be within reach for Colombian trade unionists. But it is too early to say whether or not this ray of hope is too little, too late. That is, with the country's labor movement so depleted since the post-1990s wave of neo-liberal privatization, the most pressing challenge is to resist extinction.

\section{ACKNOWLEDGEMENTS}

I would like to thank the Social Science and Humanities Research Council of Canada for its generous support that enabled research for this piece. I am very grateful to Barbara Sobol, Librarian at University of British Columbia - Okanagan for her enlightening and extraordinary assistance.

\section{NOTES}

1. 284 of the 527 assassinations of trade unionists globally occurred in Colombia between 2005 and 2009.

2. Aviva Chomsky is author of Appalachia and Colombia: The People Behind the Coal, and her interview appeared in Philadelphia Media Center, June 16 2009, www.phillyimc.org.

3. In fact, contract security forces from Colombia have turned up to perform private security in the United Arab Emirates during the 'Arab Spring' of 2011. See New York Times, 14 May 2011.

4. Interview by author with twelve workers for the Sintraimagra union in San Alberto, Cesar, Colombia, 14 February 2011. Names of workers are kept anonymous by author for security of workers.

5. Interview by author with 15 workers from palm plantations in Meta, Colombia, held at the office of Sintraimagra, Bucarramanga, 15 February 2011.

6. See Thucydides, History of the Peloponnesian War, Landmark edition, on his discussion of greed and power maximization, for example, on pages 7 and 200-2; see Machiavelli, The Prince, p 41 on his discussion of greed. 
7. For Thucydides' discussion of rupture, see History of the Peloponnesian War, op. cit., p.1, where he notes his objective account of history, and frequent references to how his approach differs epistemologically from Homer, p. 9; for his discussion of capital, see p. 9, where he discusses the relation between tyrannies and the accumulation of wealth; on page 233 Thucydides makes the important argument that peace is only achieved by generosity on the part of the strong; throughout the book, Athens loses its relative power to Sparta due to the gravitation of Athens' former colonies to the Spartan camp to avoid Athens' exploitation and enslavement, see pages 99, 309, and 472.

8. See Machiavelli, The Prince, op. cit, where he discusses consent in the sense that the Prince needs the favor of the people, pp 65, 66 and 35; see Machiavelli, The Discourses, where he discusses how to govern in a Republic, where consent of the population is key for the ruler, for examples, pages 108 and 459.

9. See Michel Foucault, The Order of Things, throughout the book he notes epistemological ruptures that are the same eras noted by Marx in political economy terms, for example, pre-classical thought is feudalism, classical thought is mercantilism, modern though conforms to industrial capitalism, and so on.

\section{REFERENCES}

\section{Interviews}

Alvis, G. (2005). Ex Presidente, Junta Nacional Union Sindical Obrera (USO). Bogotá: 24 May.

Castro Forero, A. (2008) Secretary General, Fedepalma. Bogotá: 4 June.

Correa, G. (2011) Director of Research, Escuela Nacional Sindical. Medellin: 16 February.

García C. (2009) Teniente Coronel Ricardo, Coordinador Convenios de Colaboracion Ejército. Bogotá: 14 May.

Gómez, J.R. (2004) Presidente, Confederación General de Trabajadores Democráticos. Bogotá: 5 August.

Malagón, L. (2011) Comisión Colombiana de Juristas. Bogotá: 11 August.

Mora Fodoy, T. (2006) Fiscal de la Central Unitaria de Trabajadores de Colombia. Bogotá: 12 July.

Osman Mantilla, G. (2007). Vicepresidente, USO Nacional. Bogotá: 27 November.

Ramírez, J.E. (2004) Relaciones Publicas, USO Nacional. Barrancabermeja: 9 August. 
Ríos, J.R. (2006) Presidente, USO. Bogotá: 14 July.

Ríos, J.R. (2004) Secretario General, USO. Bogotá: 4 August.

Rodríquez Ortega, E. (2009) Director, Derechos Humanos, USO Cartagena. Cartagena, 18 May.

Rosda Duque, J.B. (2004) Coordinador, Area de Derechos Humanos y Laborales, Escuela Nacional Sindical. Medellín: 2 August.

Shipipull, N. (2004) Director, Proyecto OIT/USDOL, Organizacion Internacional deTrabajo. Bogotá: 5 August.

Silverman, J. (2008) Investigadora, Escuela Nacional Sindical. Medellín: 23 June.

Támara Rivera, R. (2004) Director, Departamento de Relaciones Internacionales, Central Unitaria de Trabajadores de Colombia. Bogotá: 6 August.

Torrado, Á. (2004) Member of Directorate, USO Cartagena. Cartagena: 9 August.

Unda, J.R. (2008) Director, Gestion Social, Ecopetrol. Bogotá: 4 June.

Vaca Cespedes, H.Y. (2005) Presidente, Junta Nacional, USO. Bogotá: 24 May.

Vásquez, J. (2007) Member of Junta Directiva, USO Cartagena. Cartagena: 21 November.

Diaz, V. and Cesar, J. (2008) Hydrocarbons Director, Ministerio de Minas y Energia. Bogotá: 4 June.

Texts

AFL-CIO (2011) 'AFL-CIO remains Opposed to Colombia Trade Deal'. Available at: www.blog.aflcio.org, [Accessed 6 April 2011].

Bentham, J. (1995) The Panopticon Writings. London: Verso.

Boons, F. and Mendoza, A. (2010) 'Constructing Sustainable Palm Oil', Journal of Cleaner Production 8(16): 1686-1685.

Buchanan, P. (1989) 'Useful Foods as Diplomatic Tools: Organized Labor as an Instrument of US Foreign Policy in Latin America', paper presented at the conference on 'The United States and Latin American Democracy', University of Southern California, April 6-9.

Caicedo, E. (1971) Historia de las Luchas Sindicales en Colombia. Bogotá: Ediciones CEIS. 
Cardon Alzate, C. (2009) 'Perspectivas de la produccion de biocombustibles en Colombia', Universidad de los Andes, unpublished academic paper.

Chomsky, A. (2007) Appalachia and Colombia: The People Behind the Coal. New York: Casa Editorial Pisando Callos.

Colombia Reports (2011) 'Pipeline Bombings', 4 May.

Corely, R. (2009) 'How Much Palm Oil Do We Need', Environmental Science and Policy 13(2): 134-138.

The Economist (2009) 'Colombia', 23 April.

El Tiempo (2011) 'La Economia’. 14 May.

Ejército Nacional de Colombia (2000) Ministerio de Defensa, 'Los Grupos Ilegales de Autodefensa de Colombia'. December (mimeograph).

Escobar, A. (2003) 'Displacement, Development and Modernity in the Colombian Pacific', International Social Science Journal 55(175): 157-168.

Escobar, A. (1995) Encountering Development. Princeton University Press.

Ecobar, J. (2009) 'Biofuels: Environment, Technology, Food Security', Renewable and Sustainable Energy 13(6): 1275-1287.

Escuela Nacional Sindical (2009) 'Una Política de Exclusion Sistimatica,' mimeograph. May, p. 13.

Escuela Nacional Sindical (2002) 'Censo', Medellin, pamphlet.

Esteve, G. (1991) 'Who Needs Development?', Journal of Developing Societies 15(1): 1-31.

Esteve, G. (1987) 'Regenerating People’s Space’, Alternatives 12(198): 143-150.

Foucault, M. (2000) 'The Birth of Biopolitics', in P. Rabinow (ed), Ethics: Subjectivity and Truth (pp. 73-80). New York: Free Press.

Foucault, M. (1997) Society Must be Defended. New York: Picador.

Foucault, M. (1970) The Order of Things. New York: Vintage. 
Fuerzas Armadas Revolucionarias de Colombia (FARC) (1994) 'Manuel Marulanda Vélez, Texto Completo de Discurso Pronunciado', 27 May. Available at: www.farg-ep.org. [Accessed: 3 January 1999]

Fundacion Pais Libre (2009) Estadisticas Secuestros. Available at: www.paislibre.org/images/pdf/secuestroestadisticas\%202006\%org.pdf [Accessed 6 December 2009].

Gobierno de Colombia (2002) DANE, 'Población Económicamente Activa y Número de Sindicalizados', pamphlet.

González, F. (1975) Pasado y Presente de Sindicalismo Colombiano. Bogotá: Centro de Investigación y Acción Social.

Gramci, A. (1971) Prison Notebooks. New York: International Publishers.

Hristov, J. (2009) Blood and Capital - the Paramilitarization of Colombia. Ohio University Press.

Khondker, H. (1999) 'From Development to Post-Development', Southeast Asian Journal of Social Science 27(3): 163-172.

Leal Buitrago, F. (2002) Seguridad Nacional a la Deriva: Del Frente Nacional al la Posguerra Fria. Bogotá: Alphaomega.

Machiavelli, N. (1985) The Prince. New York: Mentor.

Machiavelli, N. (1970) The Discourses. New York: Penguin.

Martinez, D. (2010) 'Life Cycle Assessment for Joint Produciton of Biodiesel and Biothanol from African Palm', Chemical Engineering Transactions 21: 1314- 1319.

New York Times (2011a) 'Arab Spring'. 14 May.

New York Times (2011b) 'Biofuels Push Becomes Weapon in Colombia's War on NarcoTraffickers', 2 May.

New York Times (2005) 'Colombia’s Capitulation', 4 July.

New York Times (2000) 'Colombia's Economy', 26 April.

Pecaut, D. (1973) Politica y Sindicalismo en Colombia. Bogotá: La Carreta. 
Pinzon, L. (2007) 'Colombia: Biofuels Annual 2007’, United States Department of Agriculture, Foreign Agriculture Service, mimeograph.

Pye, O. (2010) 'The Biofuel Connection: Transnational Activism and the Palm Oil Boom', Journal of Peasant Studies 37(4): 851-874.

Rochlin, J. (2011) 'Plan Colombia and the Revolution in Military Affairs', Review of International Studies 37: 715-740.

Rochlin, J. (2007) Social Forces and the Revolution in Military Affairs: the Cases of Colombia and Mexico. New York: Palgrave Macmillan.

Rochlin, J. (2003) Vanguard Revolutionaries in Latin America: Peru, Colombia and Mexico. Boulder:

Romero, M. (2003) Paramiltares y autodefensas, 1982-2003. Bogotá: IEPRI.

Romero, M. (1999) 'Elites Regionales, Identidades y Paramilitares en el Sinú', in R. Peñaranda and J. Guerrero (eds), De Las Armas a la Politica (pp. 175-218). Bogotá: Tercer Mundo.

Saffard, F. and Palacios, M. (2002) Colombia: Fragmented Land, Divided Society. New York: Oxford University Press.

Spalding, H. (1976) 'The Dynamics of Imperialist Control', Latin American Perspectives 3(1): 5-69.

Thucydides (1996) History of the Peloponnesian War. Landmark edition. New York: Free Press.

United Nations (2003) Final Report of the United Nations Commission on Human Security. New York: UN.

Urritia, M (1969) The Development of the Colombian Labor Movement. New Haven: Yale University Press.

Walker, R. (1993) Inside/outside: International Relations as Political Theory. Cambridge Cambridge University Press.

World Bank (2000) Distribution of Income and Consumption. Washington: World Bank.

Yanez, E (2009) 'The Energy Balances in the Palm Oil Derived Methyl Ester Life Cycle for the Cases of Brazil and Colombia', Renewable Energy 34: 2905-2913. 


\section{BIOGRAPHICAL NOTE}

JAMES ROCHLIN is Professor of Political Science at the University of British Columbia Okanagan. He is the author of numerous books and articles on matters of Inter-American security. His most recent book is Social Forces and the Revolution in Military Affairs: the Cases of Colombia and Mexico (New York: Palgrave Macmillan, 2007). 